\title{
Religious Symbols in Public Schools: Key Issues and Debates
}

\section{Aleš ČrnNiČ ${ }^{1}$ AND ANJA PogAČNIK ${ }^{2}$}

$\approx$ When discussing Religious Education, the topic of religious symbols in educational spaces is largely overlooked in academic literature and often side-lined in political considerations as well. This paper examines the issue of religious symbols in public schools by highlighting two foci: how the Muslim veil is managed in public schools in select European countries and zooming in on specific suggestions for managing religious symbols in public schools in Slovenia. By combining a broader, comparative perspective with practical, small-scale policy suggestions, the paper highlights the need to include a discussion of religious symbols in public schools in our academic and political considerations of religion and education.

Keywords: Muslim veil, public school, policy recommendations, religious symbols, Slovenia 


\section{Religiozni simboli v javnih šolah: ključna vprašanja in dileme}

Aleš Črnič In Anja PogaČnik

$\propto$ V akademskih obravnavah religijskega izobraževanja je tematika religioznih simbolov v šolskih prostorih pogosto spregledana, podobno pa je tudi v političnih premislekih. Članek analizira problematiko religioznih simbolov v prostorih javne šole, tako da se najprej osredini na reguliranje zakrivanja muslimank $\mathrm{v}$ javnih šolah izbranih evropskih držav, potem pa še na primer konkretnih strokovnih priporočil za reguliranje religioznih simbolov v slovenskih javnih šolah. S kombiniranjem širše primerjalne perspektive in praktičnih priporočil za politično regulacijo avtorja poudarita potrebo po vključevanju problematike religioznih simbolov $\mathrm{v}$ akademske in politične premisleke religije in izobraževanja.

Ključne besede: zakrivanje muslimank, javna šola, politična priporočila, religiozni simboli, Slovenija 


\section{Introduction}

While the content of and provisions for religious education in public schools is an oft-examined topic, another, hidden - though arguably more visible - side of religious education is the management of religious symbols in public educational spaces. With the advent of modern secularity and the increased pluralisation of the $21^{\text {st }}$ century, the marking of school spaces with Christian symbols is no longer a foregone conclusion. Simultaneously, pupils (and to a lesser extent teachers) are increasingly entering educational spaces with visible symbols of their minority religious affiliation (e.g., Muslim girls and women wearing veils), which challenge the - until recently - prevailing image of a religiously homogenous European society, as well as problematises the principle of equality ensured by modern democratic societies (see Evans, 2009). National public schools are responding to these new challenges of growing plurality in different ways: some (like France) by altogether abolishing religious presence in public schools, while others (like Italy) by embracing Christian symbols as a cultural presence on the walls of their public schools, but at the same time much more strictly regulating symbols of minority religions.

Little has been written on the topic of religious symbols and public schools. Malcolm D. Evans's book Manual on the Wearing of Religious Symbols in Public Areas is one of the few monographs that address the topic explicitly, although only as a subsection of a more extensive discussion. Other authors have dealt with smaller areas of the broader debate, whether focusing on particular countries (e.g., Howard, 2009), specific notable examples like the Christian crucifix (e.g., Temperman, 2012) or Muslim veil (e.g., Criscola, 2018), or focusing on other issues with a symbolic religious dimensions, such as the availability of religious diets in school cafeterias (e.g., Twiner, Cook, \& Gillen, 2009). With this paper, we hope to add a piece to the small but growing mosaic of scholarship on religious symbols in public schools and highlight the need for both academic and political attention to be given to this 'hidden' intersection of religion and education.

This paper will address the fundamental debates around encounters between religious symbols and public educational spaces by focusing on two nexuses of policy adoption: firstly, a broader bird's-eye view of different ways European countries are dealing with the management of Muslim veils in their school spaces, and, secondly, focusing on a single country - Slovenia - and the expert recommendations presented to its Ministry of Education on religious symbols and practices in public schools. As will be shown in the broader 
comparative analysis, countries choose different ways to promote democratic values of religious freedom and equality. And the practical, small-scale example of Slovenian recommendations for the systemic handling of such dilemmas will highlight the need for regulation as well as the more principled and inclusive management of religion in public schools.

\section{Contexts and concepts}

Historically speaking, European societies were predominantly Christian, which made the question of religious presence in educational spaces unproblematic. After all, many countries trace the start of their educational systems to church-run schools. However, two developments have problematised the previously normalised marking of public spaces with Christian symbols: the modern secular state (presupposing at least a minimal distance between state and religion) and the growing pluralisation of contemporary societies (despite the fact that most European states continue to have at least nominally Christian majorities). Crucifixes on school walls now pose questions of religious freedom and the equality of religious and non-religious views, since such Christian markings of public spaces potentially symbolically exclude all those (non-Christians and non-religious) who do not identify with them. In this way, the symbolic marking of public educational spaces with Christian artefacts could mean a violation of the fundamental human right to religious freedom, which is inseparable from the right to alternative - including non-religious - beliefs. ${ }^{3}$

The second dilemma facing religiously ever more plural European societies is the question of visible ${ }^{4}$ religious symbols brought into school spaces by pupils and teachers. In the past, the marking of classrooms with crucifixes and the presence of clerical garb among teachers was customary in European schools yet has more recently become understood as the symbolic equation of public education with Christianity, in consequence excluding all other religious and non-religious traditions. Conversely, pupils (and to a lesser extent teachers) are ever more frequently entering school spaces with visible signs of their other/minority religious affiliation; for example, Muslim girls and women wearing

3 The complexity and arguments for and against religious symbols in public schools were well presented in the Lautsi case (Lautsi and others v. Italy), which the European Court of Human Rights deliberated twice, with radically different outcomes: the Lower Chamber of the ECtHR agreed with the plaintiff that crucifixes on walls of Italian schools represented a human rights violation, while the Grand Chamber ruled that crucifixes do not breach the plaintiff's right to raise her children according to her own beliefs, nor the child's right to the freedom of thought, conscience. and religion (see Andreescu \& Andreescu, 2010;_Temperman, 2012).

4 Technically, the problem of religious symbols in public schools does not originate in their presence, but their visibility; the problem arises, when/if symbols are recognised as religious (Kodelja, 2011, pp. 7-8). 
veils, or Sikh boys and men wearing turbans (or - more contentiously - ritual daggers, called kirpans).

Formal regulation of the above issues, of course, differs between European countries, and individual solutions are dependent on a number of factors. Chiefly, it depends on the religious characteristics of the society in question; whether it is a mono-, bi-, or multi-confessional society and into which religio-cultural pattern we could position it: the Latin (predominantly Catholic) pattern, the Scandinavian/Lutheran pattern, mixed (with equivalent numbers of Catholics and Protestants), or Orthodox (see Martin, 1978). Different countries developed different legal systems under the influence of the mentioned socio-religious dimensions; therefore, today's Europe has countries with close relationships between church and state (some even have state religions, ${ }^{5}$ e.g., Denmark and the United Kingdom) as well as explicitly secular countries with constitutional separation between church and state (e.g., France and Slovenia).

Regardless of the heterogeneous historical and cultural traditions impacting the various formal regulations of European countries, almost all are signatories of different international documents that enshrine the foundational principles of modernity (such as human rights, tolerance, pluralism, etc.) and that are underpinned by the precondition of a neutral state (and its public school). These international declarations ${ }^{6}$ ensure the respect of religious freedoms for children and their parents, which consequentially also impacts the field of educational policies. All the declarations and conventions respect the different historical, cultural, and legal specificities of their signatories and thus allow for a level of autonomy in the formulation of regulations within national borders. That means that they allow for the curtailment of religious freedom, but only under strictly specified and legally defined conditions, such as if one's religious freedom was to interfere with other human rights and freedoms, or jeopardise public peace, public health, or general safety of the public (see Evans, 2009, pp. 89-95). Nevertheless, the signatory countries have to consistently respect the fundamental principles of these international documents, though, in practice we witness different interpretations and implementations of the above international regulations in national environments.

5 There are ever fewer such countries; for example, in 2000 Sweden finalised a long-coming plan to abolish a state church (Pettersson, 2011), followed in 2012 by Norway (Morland, 2018).

6 Universal Declaration of Human Rights from 1948, European Convention on Human Rights from 1953, Convention Against Discrimination in Education from 1960, International Convention on Economic, Social and Cultural Rights from 1966, and Convention on Rights of the Child from 1989. 
If we look in particular at the European Convention on Human Rights ${ }^{7}$ (ECHR) and its Article $9,{ }^{8}$ there have been numerous court cases brought before the European Court of Human Rights (ECtHR) (which oversees the implementation of the Convention and issues judgements and advisory opinions); several cases involved restrictions on religious symbols, whether they allegedly happened in prisons, ${ }^{9}$ hospitals, ${ }^{10}$ courtrooms,${ }^{11}$ schools,${ }^{12}$ or public spaces in general. ${ }^{13}$ The vast majority of these cases involved religious head-covering or the Muslim veil ${ }^{14}$ in particular. When considering the sphere of public education, the dominance of cases centring on Muslim headscarves is apparent - five out of seven cases concerning religious symbols in educational institutions involved girls and women restricted from wearing Muslim headscarves (the other two involved crucifixes displayed in classrooms and a prohibition on wearing the Sikh keski or under-turban for six French boys). Italy (with one case), Switzerland (with one case), Turkey (with three cases), and France (with two cases) were the countries against which these violations of Article 9 of the ECHR were alleged. If the cases brought before the ECtHR are to be any indication, the issue of Muslim veiling is a pertinent one, not only on the international/European level but also on national levels.

\section{The Case of the Muslim Veil}

The issue of the Muslim head-covering is, of course, an intensely politicised one, correlated with wider political swings towards nationalism, populism, and Islamophobia noticeable in many European countries. Therefore, it should

7 Formally known as the Convention for the Protection of Human Rights and Fundamental Freedoms, adopted in 1953 and signed by forty-seven countries.

8 It states: (1) Everyone has the right to freedom of thought, conscience and religion; this right includes freedom to change his religion or belief and freedom, either alone or in community with others and in public or private, to manifest his religion or belief, in worship, teaching, practice and observance. (2) Freedom to manifest one's religion or beliefs shall be subject only to such limitations as are prescribed by law and are necessary in a democratic society in the interests of public safety, for the protection of public order, health or morals, or for the protection of the rights and freedoms of others.

9 Austarianu v. Romania, Kovalkovs v. Latvia, for a cultural analysis see McIvor, 2015.

10 Eweida and others v. UK.

11 Barik Edidi v. Spain, Hamidović v. Bosnia and Herzegovina, Lachiri v. Belgium.

12 Lautsi and others v. Italy, Dahlab v. Switzerland, Kurtulmus v. Turkey, Leyla Sahin v. Turkey, Köse and 93 others v. Turkey, Dogru v. France, Kervanci v. France, Aktas, Bayrak, Gamaleddyn, Ghazal, J. Singh, R. Singh v. France.

13 Ahmet Arsian and others v. Turkey, S.A.S. v. France, Belcacemi and Oussar v. Belgium, Dakir v. Belgium.

14 In this paper, we use 'Muslim veil' as a catchall term for Muslim covering of female body parts, while also using headscarf (for covering of the hair), face veil (covering the face in addition to hair; also niqab), and burqa (referring to a set of clothing that cover the wearer's hair, face, and entire body) to refer to specific items of clothing. 
be no surprise that countries in which xenophobia, Islamophobia, and nationalism have grown in visibility over the past few years are also the countries where we encounter more numerous and wide-ranging calls for general or specific bans on Muslim women wearing veils.

Erica Howard (2009) identified five general arguments typically invoked when promoting such bans on (Muslim) religious symbols and clothing (both in schools and public spaces): 1) safety/security reasons as a measure against terrorism; 2) to reduce the separation/segregation signalled by the Muslim veil and encourage integration; 3 ) to enable better communication (including verbal and non-verbal); 4) to prevent oppression of women (symbolised by the Muslim veil) and promote gender equality; and 5) to preserve state secularity and the separation between church and state (ibid., pp. 10-12). These five arguments for bans are typically countered with a range of arguments against them, but four major ones argue that a ban would be: 1) a breach of the human right to freedom of religion (in relation to schools it would also breach the right to education); 2) an interference with a woman's right to equality and protection against discrimination; 3 ) it would be based on stereotypes about Muslim beliefs and practices, and 4) there is no evidence that such bans would actually increase safety and/or improve social cohesion (ibid., pp. 12-13).

Although some countries have instituted general bans on wearing face veils (niqab or burqa) in public spaces (e.g., Austria, Belgium, and France), others have for now more or less skilfully avoided the capture of the public political space and individual religious freedoms by the proponents of such bans (e.g., the UK and Germany). However, there are many more that are at present exhibiting shifts and drifts that are either evidently moving towards the explicit regulation of Muslim women's headwear, or are in danger of doing so: Denmark, Italy, and Spain are among them.

The authors of this paper, while not proposing a one-size-fits-all solution or even propagating a single idea of how countries and their national educational systems should approach the issue of Muslim head-covering, nevertheless do believe that general bans on Muslim headscarves (such as the one implemented in France under their strict laïcité policy) are infringing on people's - specifically, women's - ability to practice their religion and tend to do more harm than good. They might further alienate an already infringed group and further legitimise Islamophobia within the country's borders. Nevertheless, we recognise the need for regulation of clothing within educational institutions and that co-existence of different beliefs, practices, and lifestyles necessitates a degree of compromise and adjustment. 


\section{Strategies and Policies Adopted by Different European Educational Systems}

Approaching the topic of Muslim veils in the spaces of public schooling, we can highlight several aspects that tend to influence the guidelines for dealing with their presence. The guidelines' legal status (whether they are legally binding or only indicative), their scope (applying to teachers, teachers and pupils, or even to the pupils' parents entering educational premises), the approaches to handling regulation (whether it approaches problems on a case-by-case basis, or seeks to manage them with general rules), the influence of the broader public discourse on their substance (such as the problematic portrayals of Muslims as dangerous, backward, or less entitled to their democratic rights), or even their mere existence (many countries do not currently have any official guidelines on managing religious symbols in public schools, including Muslim veils). For the sake of brevity, the following analysis will focus on the most fundamental aspect of regulating Muslim veiling in public schools, that is the nature of such guidelines: whether they are liberal or restrictive towards the women entering schools with their heads covered for religious reasons. We will look at a select number of cases that fall somewhere along the spectrum from very restrictive to very liberal regulatory policies on religious head-covering in public schools and examine their specific features.

\section{Restrictive policies}

When thinking about examples of restrictive policies towards Muslims, France is almost the paradigmatic example. It was the first country in the European Union to legalise a ban on Muslim face veils in public spaces, invoking the foundational concept of laïcité as its basis. The groundwork for this prohibition was first established in 1983, when France adopted a blanket ban on religious clothing and symbols for all employees of all its public institutions (including public education). France later introduced a law banning 'ostentatious' religious symbols (like the headscarf, large crosses, turbans, etc.) in public spaces in 2004, and then in 2011 specifically targeted public displays of Muslim faceveiling with the act On the Prohibition of Concealing the Face in Public Space (see Criscola, 2018, pp. 37-44). Although the 2004 adoption of the national ban on Muslim headscarves (and other 'ostentatious' religious symbols) included public schools and legally restricted pupils' rights to manifest their religion, it was not the first time such a regulation was introduced. Ten years earlier (in 1994) the Minister of Education published a circular, which officially allowed 
public schools to ban 'ostentatious' religious symbols thought to be intrinsically proselytising and discriminatory. Yet even earlier than that individual schools refused enrolment or expelled students for wearing religious symbols and numerous legal cases arose from 1989 onward around pupils who refused to take off their headscarves and were consequently expelled from schools. Two secondary school students, who were expelled after refusing to take off their headscarf during physical education in 1998/1999 took their cases all the way to the European Court of Human Rights, although the Court did not find in their favour (see Dogru v. France and Kervanci v. France).

Belgium is likewise a country with restrictive policies towards its Muslim inhabitants wearing a headscarf. In the post-9/11 world, the Belgian rhetoric against Muslims has intensified, and in 2011 the Belgian federal parliament adopted a legal ban on face veiling in public spaces with unanimous support. They cited public security and the liberation of women as two main reasons for such a ban, although Muslim head-covering was not directly mentioned in the wording of the law (the law was nevertheless widely regarded as 'the burqa ban'). Recently, there have been further efforts to institute a ban on veiling for all public employees.

The Belgian educational system is uniquely fragmented (into three language groups and between the public and private sectors, in the latter of which the majority of pupils attend schools run by the Catholic Church [see Torfs, 2011]), although there is nevertheless a tendency towards banning visible (nonChristian) religious symbols. 'The French-, Flemish-, and German-speaking communities in Belgium all have decrees demanding neutrality from teachers in public schools that are part of the community network' (Criscola, 2018, p. 22) and the majority of primary and secondary schools do not allow religious symbols for either teachers or pupils. Exceptions are made for teachers of religion or moral ethics classes, who are allowed to wear visible and explicit religious symbols, yet there have been cases in which Muslim RE teachers have been asked to remove their headscarves outside RE classes, or an RE teacher that was refused the job for wearing a veil. Furthermore, certain schools also ban parents of pupils from wearing headscarves when volunteering for school activities and extreme cases have been reported of children not being allowed to wear hats in winter because it could be used as a justification for Muslim head-covering (ibid., pp. 22-25).

The Netherlands, a country in which only about one hundred women consistently wear a face veil, four hundred do so occasionally, and none are reported to wear a burqa (Moors, 2009), approved a partial ban on face-veiling in June 2018, which applied to public transport, educational spaces, healthcare, 
and public government buildings. Although no complaints or problems were ever raised around women wearing face veils, the far-right Freedom Party (PVV) led by Geert Wilders had been advocating for different kinds of bans on Muslim headwear since their first proposed 'burqa ban' in 2005; Wilders even proposed a special tax on headscarves in 2009, giving it a derogatory name of 'head rag tax' (Criscola, p. 61). Yet the ostracising of Muslim women wearing head-coverings has not been limited to political posturing and media discourse. Certain schools and universities (e.g., the University of Leiden) prohibit wearing face veils for their staff and students for communication and identification reasons (ibid., p. 63).

\section{Liberal policies}

While the countries with general or partial bans on Muslim veils are the exception rather than the rule in the European Union, truly liberal policies are also a rarity and even the countries that will be discussed here, under the 'liberal' heading, embrace diversity within their societies and schools to limited extents. It should be said, therefore, that there are no fully liberal policies, just as there are no fully restrictive ones (though there are certainly some very restrictive ones, as discussed above). Nevertheless, we can draw distinctions between different groupings of policies on an ideal-typical level.

The United Kingdom is a country typically heralded as one of the most accepting of visible religious symbols. ${ }^{15}$ Religious clothing like the Muslim veil and the Sikh turban are incorporated into the uniforms of public servants, pupils, and even royal guards, and although less common, the Muslim face veil is allowed in public spaces and certain occupations as well. At the time of writing, there were no bans pertaining to Muslim veiling in the UK, despite the recent rise in Islamophobia and occasional debates about Muslim veiling. ${ }^{16}$ The vast majority of British schools allow and actively incorporate headscarves in their school uniforms, yet every school has the authority to dictate their own dress, which has led to a handful of cases in which visible religious symbols led to heated debates and expulsions from schools (see Howard, 2009). In most cases in which legal action was taken on behalf of girls and women wearing veils, their expulsions were deemed lawful, because alternative schools were available in the area allowing the wearing of the item of Muslim clothing in question and, therefore, the ability of pupils to obtain an education had not been interfered with (Criscola, 2018, p. 76).

15 Which can also be attributed to its specific imperialist history bringing people from multiple cultures and religious traditions to the British Isles since the very beginning of the British Empire.

16 The UK Independence Party and the British National Front failed in their attempts to ban veils, as the proposals they put forth between 2010 and 2013 were rejected by the parliament. 
Although fragmented among its sixteen federal states in their level of Islamophobia, Germany is another example of a somewhat liberal policy towards Muslim veiling in public spaces as well as schools, at least on the national level. Eight out of its sixteen states (Bundesländer) have enacted some sort of bans relating to Muslim face veils, and Islamophobic attacks have been on the rise, yet national politics have so far avoided adopting a ban on face veiling (although Chancellor Angela Markel came out in support of 'burqa bans' in schools, courts, and state buildings in December 2016). In our context, however, a case to highlight is the ruling of the Federal Constitutional Court in March 2015, when it 'decided that a blanket ban on headscarves and other visible religious symbols for teachers at a state school violates the freedom of religion, and is not compatible with the Constitution because it is disproportionate' (ibid., p. 46). Unless a school can prove wearing a Muslim headscarf poses a danger to the school's peace or the state's neutrality, a general ban is unjustified.

\section{The in-betweens}

As already pointed out, the countries mentioned above are not solely 'restrictive' or solely 'liberal', and there are many more that fall somewhere in between. They either tend towards the liberal end of the spectrum or the restrictive one, although recently a trend towards a more restrictive set of policies can be detected in Europe. These 'in-between' countries, therefore, represent the battleground of ideologies for the future of European responses to the presence of Muslim veils and other non-Christian religious symbols in their educational spaces. At present, restrictive policies appear to be gaining ground.

The starkest example of this slide toward restrictive policies not only in schools but also in public spaces is Denmark. In May 2018, the Danish parliament passed a law banning face veils in public spaces, despite the fact that only a very small number of Muslim women in Denmark wear the face veil, many of them Danish converts. The 2018 general ban was built on the 2009 law that bans judges from wearing religious or political symbols (including crucifixes, headscarves, skullcaps, turbans, etc.) and the 2016 call by the Danish People's Party to extend the law to public schools and hospitals (ibid., p. 32). Although the 2018 general ban is relatively new, there have been cases of adult students banned from wearing face veils and Denmark has seen a general rise in Islamophobia, especially after the Jyllands-Posten controversy involving the caricatures of the prophet Muhammad in 2005. 


\section{A Practical Example of Systemic Guidelines: Slovenian Expert Recommendations}

We now want to turn to a more practical side of policy dealing with religious symbols in public schools: an example of recommendations for systemic guidelines in Slovenia. The county would mostly fit in the above category of 'in-betweens', as it does not have a coherent policy on religious symbols in public spaces, yet most of its practices would fit into a liberal type: there are no general or partial bans on Muslim veils (or other ostentatious religious symbols), and there are no guidelines prohibiting the wearing of religious symbols (including Muslim veils) in public schools for pupils or teachers. In fact, there are no guidelines on the management of religious symbols in public schools in general. This poses a problem when school principals encounter religious symbols or practices and do not know how to act, potentially leading to, on the one hand, curtailing of religious expression for Muslim pupils and, on the other, invitations to Catholic benedictions of new buildings. ${ }^{17}$ Such a loose and unregulated field thus gives autonomy to individual schools to dictate their own policies in relation to religious symbols/actions, which sometimes poses a problem: an issue that is slowly being recognised by the Slovenian state as in need of addressing.

When Slovenia declared independence from Yugoslavia in 1991, the initial decision of the state was not to regulate the relationship between public school and religion (i.e., the Roman Catholic Church, with which the majority of Slovenes affiliate), ${ }^{18}$ especially since restrictive regulation could paradoxically provoke new problems (Kodelja, 2011, p. 57). Since 1991, Slovenian society has gradually changed in its religious composition, becoming slightly more diverse, and the Ministry of Education has started receiving requests from school principals to advise them on how to act in concrete cases of (non-Christian) religious symbols entering school spaces, while the pressure of the Catholic Church for a more visible presence in schools has not abated. Noticing the need to revise its initial decision to not regulate the field of religion and education, the Ministry of Education engaged a handful of experts to prepare expert opinions as the basis for solving such dilemmas in a systematic way and in accordance with the Slovenian constitution and its cultural traditions. In the past

17 Although illegal, Catholic benedictions of public schools nevertheless happen in Slovenia, arguably due to the unclear reinforcement of the law (ZOFVI, \$72) through practical guidelines and policies.

18 Around $70 \%$ of Slovenes express affiliation to the Roman Catholic Church. The second biggest religious group is the Muslim community (around 4\%), followed by the Serbian Orthodox Church and the Evangelical Church with under $2 \%$ each (see Črnič et al., 2013). 
decade, the Ministry of Education thus invited one of the authors of this paper to participate in two expert commissions on religion in public schools. The first one (see Smrke, Črnič, \& Kodelja, 2009) was to provide the basis for a 'more precise determination of the relationship and/or boundaries between public school and religion' (ibid., p. 1), while the second (see Črnič \& Kodelja, 2017) was to produce an expert recommendation for 'a constructive engagement of the public educational system with the growing challenges of a religiously plural society' (ibid., p. 1).

However, none of the expert reports has resulted in any formal guidelines, regulations, or policies. The results of the first expert commission ended up in a ministerial drawer without any practical results and the recommendations of the second were swept up in the 2018 general elections without leading to any official documents or regulations (though internal sources say the Ministry does utilise them as a basis for formulating responses to problems facing individual schools). Recently the Ministry did, however, order a smaller research project (with this paper being its interim result) to acquire conceptual and comparative bases for the formulation of a comprehensive strategy around this issue. The question remains whether such a strategy will actually see the light of day.

\section{Recommendations of the Two Expert Commissions}

Despite the fact that the Slovenian state did not yet form any official guidelines based on the two expert commissions it appointed, we will nevertheless present some of the basic frameworks they proposed below, not so much because they would be universally applicable to other contexts, but to present them as an example of an expert recommendation on the problem at hand in a specific cultural and legal context of Slovenia and the Slovenian society. In that we are referring primarily to the legal separation of State and Religion (and religious communities in general) that is written in the Slovenian constitution, and in the cultural sense the historical connection with Christianity (primarily Catholicism, though Protestantism also played a role in the formation of the Slovenian language and its national identity), which is displayed even today in the dominant position of the Catholic Church in the religious structure of Slovenian society. ${ }^{19}$

19 As mentioned above, a little more than two thirds of Slovenes affiliate with the Roman Catholic Church (RCC), and the RCC, as a value-driven religio-political entity, often interjects in political, social, and cultural debates occupying the public space, such as women's reproductive rights, legalisation of homosexual marriage, or general elections and referenda. 
The commissions based their opinion on:

interlocking constitutional principles of freedom of religious expression, the separation of church and state, state neutrality to religious and nonreligious worldviews, equality of religious communities, and the principles of public school autonomy, the primacy of educational goals, and avoiding interfaith conflicts in school spaces (Smrke et al., 2009, p. 1).

The report of the second expert commission also emphasised 'the foundational maxim of the public school: to be accessible under uniform conditions to all, no matter their financial situation, social status, nationality, gender, language, religious, political or other affiliation etc.' (Črnič \& Kodelja, 2017, p. 1). For further emphasis they added:

In Slovenia public schools are secular. Secular schools, which realise the constitutional separation of state and religious communities, have to be neutral in relation to worldviews. Such a worldview-neutral school is a school that does not force anyone to accept a particular worldview, while at the same time offering elements enabling everyone to build a worldview of one's own choosing. Therefore, it is not the task of the public school to form Catholics, Liberals, Protestants, Atheists, etc. That can only be done by private schools, families, churches, and so on, not the public school, which has to be a space of unification based on shared fundamental values, providing cultural identity and social integrity to the future generations, a space of learning about democratic behaviour, tolerance, and respect for those who think differently (ibid.)

The first expert commission focused primarily on questions surrounding benedictions at public schools, religious symbols in public schools, and the advertising of religious activities in spaces of public education. Based on the above rationale, the commission suggested a ban on benedictions (of any religious organisation), ${ }^{20}$ a ban on religious symbols (e.g., on walls), as well as a

20 The report especially highlights the problem of equating the state with (one) religion: 'If such benedictions were allowed, they should - in the spirit of our constitution - be possible for all religious communities present in any greater number in the school's catchment area. Only such a clear (temporal and spatial) separation of the religious ritual from the state/civil ceremony of inauguration and the equal opportunity for all religious communities would not express the equation of state with the church. Yet providing such equality for religious communities would in practice be incredibly difficult if not impossible, as it would necessitate a pronouncement from parents/children of their religious affiliation, which is constitutionally impermissible' (Smrke et al., 2009, p. 1). 
ban on any form of religious advertising and propaganda in spaces of public education (Smrke et al., 2009, p. 1-2). In the concluding segment of the first report, the authors emphasised that the question of pupils and teachers wearing religious symbols in the form of dress and/or jewellery required a more precise approach and regulation and the second report built on that question as its central element. The authors argued that pupils and teachers should be dealt with separately, allowing pupils to display symbols of religious affiliation (including veiling and religious dress), while teachers should be allowed only 'discrete signs/symbols of whichever religious affiliation and not conspicuous signs/symbols that would very visibly announce the connection between an individual teacher with one of the religious traditions/communities. The same holds true for dress' (Črnič \& Kodelja, 2017, p. 1). They justify the greater tolerance towards pupils by writing:

The public school must not obstruct the basic personal expression of faith/religion. [...] It has to be a space of adaptation to diversity, difference, and exceptions. The secularity of public school ensures its neutrality, in turn assuring the equal participation to all subjects, regardless of worldview or other differences (it ensures this by creating a neutral space into which the subjects enter in their difference, without being forcibly uniformed). Therefore, pupils can enter public schools with more noticeable religious symbols, clothes, and so on (ibid.)

Discernibly stricter restrictions in the case of teachers are justified with the argument that teachers 'represent the institution of public school, which is secular and neutral, and they have to express this with their appearance as well. Therefore, more conspicuous religious symbols, clothes, and so on (e.g., Muslim veils, Catholic habits, etc.) cannot be allowed' (ibid., p. 2). Yet even pupils' ability to wear religious symbols in schools is curtailed in the expert recommendations by two limitations: that such clothes/jewellery must not interfere with the pupils' ability to participate in the general curriculum (with customised clothing like the burkini being allowed), and that they must not prevent the personal identification of pupils (consequently, prohibiting face veiling) (ibid., pp. 1-2). With such a combined approach of permission and restriction, the recommendations aimed to satisfy both the need to accept religious diversity within schools, while at the same time acknowledging the secularity of public schools and the practical constraints of education. 


\section{Conclusion}

When children enter public school spaces, they learn about the place of religion in their country and society not only through the curricula of Religious Education classes or other subjects covering content on religion (such as History or Literature), but also through observing how expressions of religious belief and affiliation are managed by people in places of authority. Even countries that do not have a designated RE curriculum nevertheless implicitly teach their pupils about what expressions of religiosity are acceptable and normalised within a society and which are deemed out of place and marginalised. It is therefore vital that we - either as academics, policy-makers, or concerned stake-holders - take the topic of religious symbols in schools seriously when discussing, planning, and managing the education of children.

With this paper, we have taken a look at the diversity of responses to a particular religious symbol (the Muslim veil), as well as the specificities of a particular policy proposal (in the country of Slovenia) for dealing with religious symbols in schools more widely. Having examined some aspects of the breadth and depth of the topic at hand, we now want to draw attention to a few broad conclusions of the above discussion and some of its implications as a way of emphasising the importance of the issue and the scope of the challenge in addressing it.

1. The management of religious symbols in public schools is largely dependent on the wider political climate and policy-making in the country. Whether liberal or restrictive, the macro-national policies in the general field of religion also impact the meso-context of public educational facilities.

2. Not impacted only by broader political leanings, religious symbols in schools are also - and mainly - affected by a country's social and cultural specificities. Depending on the religio-cultural pattern of a country and its society (whether it is mono-, bi-, or multi-confessional; and whether it is of a Latin, Scandinavian/Lutheran, mixed, or Orthodox pattern), the way a country deals with expressions of religious belief and affiliation in its public schools will differ from one state to the next. When formulating guidelines, regulations, or policies, it is paramount that these social and cultural factors to be taken into account.

3. When discussing religious symbols in public schools, we are not only talking about highly visible and emotionally charged symbols such as 
the crucifix or a hijab. The variety of issues covered include potential reservations of pupils/parents to certain elements of the public school curriculum (e.g., mixed-gender swimming lessons (see Walseth, 2015; ECtHR case Osmanoğlu and Kocabaş v. Switzerland)), to the general interaction between genders (e.g., the Swiss controversy related to the traditional pupil-teacher handshake (see Hetmanczyk et al., 2018)), and the above-mentioned question of religious diets in school cafeterias (see Twiner, Cook, \& Gillen, 2009). Although these are examples that were not covered in this paper (due to the constraints of space), they are nevertheless equally pertinent to the discussion of religious symbols in educational spaces and merit equal consideration.

4. With the gradual increase in religious diversity of countries around Europe in recent decades, and with the rise in nationalistic, restrictive, and Islamophobic sentiments and policies in recent years, the need for explicit regulation or guidelines on the handling of unexpected or unfamiliar cases of religious symbols in individual schools will likely increase, and academic and political discussion around it will become ever more pertinent.

5. Yet, as evident from the Slovenian example, the achievement of political movement towards the management of religious symbols in public schools in any explicit ways is likely to be difficult, laborious, and slow. Therefore, the responsibility of thoughtful discussion rests not only with decision-makers on national levels, but also with academics, educators, parents, religious communities, and other stakeholders. Although it is true that formal regulation of religious symbols in public schools is not necessary in some cases (or might even cause problems), the need for rigorous research and analysis on the issue of religiously motivated behaviours and religious symbols in public schools is nevertheless high and pressing.

We wish that our paper will not only be a small contribution to the academic discussion on religious symbols and education, but also a call to action for academics working in related fields to step up to the challenge of finding ways to address the various dimensions and issues surrounding the presence of religious symbols in public schools and help shape the way pupils, parents, teachers, principals, and regulators deal with the topic of religion's visible presence on and within the walls of their public schools. 


\section{Acknowledgements}

The research was funded by the Slovenian Ministry of Education, Science and Sport, and the Slovenian Agency for Research.

\section{References}

Andreescu, G., \& Andreescu, L. (2010). The European Court of Human Rights' Lautsi decision: Context, contents, consequences. Journal for the Study of Religions and Ideologies, 9(26), 47-74. Črnič, A., \& Kodelja, Z. (2017). Strokovna izhodišča in priporočila za konstruktivno soočanje šolskega sistema z rastočimi izzivi religijsko pluralne družbe [Expert reflections and recommendations for a constructive engagement of the educational system with the growing challenges of a religiously plural society]. Ljubljana: Internal resource of the Slovenian Ministry of Education, Science and Sport. Črnič, A., Komel, M., Smrke, M., Šabec, K., \& Vovk, T. (2013). Religious pluralisation in Slovenia. Teorija in praksa, 50(1), 205-232.

Criscola, J. (2018). Restrictions on Muslim women's dress in the 28 EU member states: Current law, recent legal developments, and the state of play. New York, NY: Open Society Foundations.

European Court of Human Rights. (2018). Factsheet: Religious symbols and clothing. Strasbourg: Press Unit of the European Court of Human Rights.

Evans, M. D. (2009). Manual on the wearing of religious symbols in public areas. Strasbourg: Council of Europe Publishing.

Hetmanczyk, P., Bürgin, M., \& White, T. (1918). The Therwil affair: Handshakes in Swiss schools. The Religious Studies Project. Retrieved from https://www.religiousstudiesproject.com/podcast/thetherwil-affair-handshakes-in-swiss-schools/

Howard, E. (2009). School bans on the wearing of religious symbols: Examining the implications of recent case law from the UK. Religion and Human Rights, 4(1), 7-24.

Kodelja, Z. (2011). Med pravico in prepovedjo [Between a right and a prohibition]. Ljubljana: Pedagoški inštitut.

Martin, D. (1978). A general theory of secularization. New York, NY: Harper \& Row.

McIvor, M. (2015). Carnal exhibitions: Material religion and the European Court of Human Rights.

Ecclesiastical Law Society, 17(1), 3-14.

Morland, E. (2018). New relations between State and Church in Norway. European Journal of Theology, 27(2), 162-169.

Pettersson, P. (2011). State and religion in Sweden: Ambiguity between disestablishment and religious control. Nordic Journal of Religion \& Society, 24(2), 119-135.

Smrke, M., Črnič, A., \& Kodelja, Z. (2009). Strokovna izhodišča za razpravo o natančnejši določitvi odnosa/meje med javno šolo in religijo [Expert reflections for a debate on a more specific determination of the relationship/boundary between public school and religion]. Ljubljana: Internal resource of the Slovenian Ministry of Education, Science and Sport. 
Temperman, J. (Ed.). (2012). The Lautsi papers: Multidisciplinary reflections on religious symbols in the public school classroom. Leiden \& Boston, MA: Martinus Nijhoff Publishers.

Torfs, R. (2011). Religious instruction in public education in Belgium. In Gerhard Robbers (Ed.), Religion in public education (pp. 63-71). Germany: European Consortium for Church and State Research.

Twiner, A., Cook, G., \& Gillen, J. (2009). Overlooked issues of religious identity in the school dinners debate. Cambridge Journal of Education, 39(4), 473-488.

Walseth, K. (2015). Muslim girls' experience in physical education in Norway: What role does religiosity play? Sport, Education and Society, 20(3), 304-322.

Moors, A. (2009). Gezichtssluiers: Draagsters en debatten [Face Veils: Wearers and Debates]. Amsterdam: Amsterdam School for Social Science Research, University of Amsterdam. Retrieved from https://www.parlementairemonitor.nl/935300o/1/j4nvgs5kjg27kof_j9vvij5epmj1eyo/ vigwbodwaltd/f=/blg21667.pdf

\section{Biographical note}

Aleš Črnič, $\mathrm{PhD}$, is a Professor of Religious Studies at the Faculty of Social Sciences, University of Ljubljana, Slovenia. Among other things, he published two books on alternative religiosities in contemporary Western world. He served as secretary general and vice-president of the International Study of Religion in Central and Eastern Europe Association and for fifteen years as president of the section for Religious Studies of the Slovene Sociological Association.

Anja Pogačnik, PhD, is a junior researcher in the field of religion and public education at the Faculty of Social Sciences, University of Ljubljana, Slovenia. Her research interests include religion and migration, South Asian diaspora, anthropology of religion, and more recently Religious Education (RE), and religious symbols and manifestations of religious belief in public schools. 